\title{
Absorção de Anticorpos do Colostro em Bezerros. I. Estudo no Intestino Delgado Proximal Rosana Bessi ${ }^{1}$, Patricia Pauletti ${ }^{2}$, Raul Dantas d'Arce ${ }^{3}$, Raul Machado Neto ${ }^{4}$
}

\begin{abstract}
RESUMO - Com o objetivo de estudar a morfologia e determinar a localização da enzima fosfatase ácida na região anterior do intestino delgado, do nascimento ao fechamento intestinal, foram coletadas amostras de 15 bezerros machos em três idades: ao nascer sem que houvesse a ingestão de colostro; três horas após a ingestão da primeira refeição de colostro e aos três dias de idade. Observou-se a presença de células vacuoladas do duodeno ao jejuno médio no recém-nascido, preenchidas por material absorvido após a ingestão de colostro. Foram verificadas mudanças nas características morfológicas aos três dias de idade, com o início da detecção de reação da fosfatase ácida em lisossomos, indicando ação enzimática sobre o material absorvido. A morfologia aos três dias de idade pode representar o diferente estádio de maturação das células epiteliais do intestino delgado de bezerros, indicando que o processo depende das características da primeira geração de células desta região do intestino.
\end{abstract}

Palavras-chave: imunoglobulinas, duodeno, jejuno, fosfatase ácida

\section{Colostral Antibodies Absorption in Dairy Calves. I. Proximal Small Intestine Study}

ABSTRACT - The objective of this study was to study the morphology and the localization of acid phosphatase at calves anterior small intestine, from birth to intestinal closure. Fifteen male dairy calves were used in this study, which were aged: unsuckled neonatal, three hours after colostrum ingestion and three days old. Vacuolated cells from duodenum to medium jejunum could be found in the newborn calf, which have shown absorbed material after colostrum ingestion. Changes at the morphological characteristics and the initiation of phosphatase acid reaction in lysosomes were observed in calves aged three days old. The three days old morphology can represent a different phase of epithelium cells maturation of calves small intestine indicating that the absorption process is dependent of the first generation of cells from this intestinal region.

Key Words: immunoglobulins, duodenum, jejunum, acid phosphatase

\section{Introdução}

Os níveis de anticorpos na circulação são insignificantes no bezerro recém-nascido, que depende inteiramente da transferência de imunidade materna para a sobrevivência e higidez nas primeiras semanas de vida. A mãe produz uma secreção muito especial, o colostro, rica em anticorpos que são absorvidos intactos e funcionais pelas células epiteliais do intestino delgado do neonato (Brambell, 1958).

Em ratos e camundongos, espécies com transferência de imunidade passiva predominantemente pósnatal, o processo de absorção de anticorpos já é conhecido em detalhes. Sabe-se que as imunoglobulinas $\mathrm{G}$ ( $\operatorname{IgG})$ das secreções lácteas ligam-se especificamente a receptores presentes nas membranas das células epiteliais do duodeno e jejuno do animal lactente. A ligação IgG-receptor, que depende do $\mathrm{pH}$ luminal, desencadeia a internalização do complexo por endocitose. Atravessando a célula, por uma rede de túbulos e vesículas, o complexo IgGreceptor é exposto na membrana basolateral e dissociase no $\mathrm{pH}$ do meio interno. O receptor é reciclado, voltando à membrana apical, e as IgGs atingem os vasos linfáticos e a circulação sistêmica (Rodewald, 1973; Rodewald, 1980; Rodewald, 1976).

Em estudos fisiológicos, observou-se que a absorção de anticorpos em bezerros ocorre principalmente nas regiões média e caudal do intestino delgado (James et al., 1979). Sugeriu-se, ainda, que os anticorpos são absorvidos por pinocitose, não se descartando a possibilidade de envolvimento de receptores (Jochims et al., 1994).

A enzima fosfatase ácida vem sendo utilizada

\footnotetext{
1 Eng. Agrôn., M.Sc., Depto. Produção Animal ESALQ-USP, Av. Pádua Dias, 11, Caixa Postal 9, CEP 13418-900 Piracicaba, SP., Tel (19) 34294260 Fax (19) 3429 4338, E-mail: piracicaba@btconnect.com

2 Eng. Agrôn., M.Sc., Depto. Produção Animal ESALQ-USP, Av. Pádua Dias, 11, Caixa Postal 9, CEP 13418-900 Piracicaba, SP., Tel (19) 34294260 Fax (19) 3429 4338, E-mail: ppaulett@carpa.ciagri.usp.br

3 Eng. Agrôn., Prof. Dr. Depto. de Produção Animal, ESALQ-USP, Av. Pádua Dias, 11, Caixa Postal 9, CEP 13418-900 Piracicaba, SP, Tel (19) 34294260 Fax (19) 34294338.

4 Eng. Agrôn., Prof. Titular, Depto. de Produção Animal, ESALQ-USP, Av. Pádua Dias, 11, Caixa Postal 9, CEP 13418-900 Piracicaba, SP, Tel (19) 34294260 Fax (19) 34294338 E-mail:rmachado@carpa.ciagri.usp.br
} 
como marcador para a demonstração de atividade de lisossomos. Em ratos, a localização simultânea dessa enzima e da IgG permitiu determinar que, nas células do intestino delgado proximal, as IgGs não são degradadas, uma vez que as vesículas em que são transportadas não se fundem a lisossomos. Já no intestino delgado distal, as IgGs são degradadas em vesículas contendo atividade de enzimas lisossômicas (Hasegawa et al., 1987). A ligação IgG-receptor garante a transferência da proteína intacta na região proximal, mas, na região distal, IgG é aparentemente degradada e não atinge a circulação.

Enquanto em ratos e camundongos o período de absorção de IgG se prolonga por todo o aleitamento, em bezerros e suínos esse processo ocorre apenas nas primeiras 24 a 48 horas de vida e o desenvolvimento da digestão intracelular pode estar relacionado ao término do período de transferência de anticorpos, processo conhecido como fechamento intestinal. Não foi detectada atividade da fosfatase ácida nos vacúolos de colostro nas células epiteliais do intestino delgado de leitões recém-nascidos (Kraehenbuhl \& Campiche, 1969). No entanto, verificou-se atividade em vesículas e vacúolos após o fechamento intestinal (Brown \& Moon, 1979). As informações disponíveis sobre o processo de fechamento são escassas em bezerros.

Este trabalho foi conduzido com o objetivo de estudar a morfologia e determinar a localização da enzima fosfatase ácida na região anterior do intestino delgado de bezerros do nascimento ao fechamento intestinal.

\section{Material e Métodos}

Coleta das amostras. Foram utilizados 15 bezerros machos, da raça Holandesa, adquiridos da Fazenda Agrindus S/A. Esses animais foram anestesiados e sacrificados para a coleta de amostras do intestino delgado, em três idades: cinco animais ao nascer sem que houvesse a ingestão de colostro; cinco animais três horas após a ingestão da primeira refeição de colostro, ocorrida na primeira hora de vida, e cinco animais aos três dias de idade, os quais após duas refeições de dois litros de colostro de boa qualidade, provenientes da própria mãe, nas primeiras $24 \mathrm{~h}$ de vida, receberam quatro litros diários de leite integral divididos em duas refeições.

Um segmento de dois centímetros de comprimento foi retirado de três regiões do intestino delgado, correspondendo ao duodeno, jejuno proximal e jejuno médio. Os tecidos foram fixados por imersão em solução de paraformaldeído 4\% em tampão cacodilato de sódio $0,1 \mathrm{M}$ e sacarose $0,2 \mathrm{M} \mathrm{pH} \mathrm{7,2} \mathrm{por} \mathrm{duas}$ horas, lavados repetidamente em tampão, para, em seguida, serem separadas amostras para microscopia óptica e eletrônica.

Microscopia óptica. Amostras de $5 \times 5 \mathrm{~mm}$ foram desidratadas em soluções de concentrações crescentes de etanol e embebidas em resina glicol metacrilato (JB4, Polysciences Inc.). Para o estudo da morfologia, secções de $5 \mathrm{~mm}$ de espessura foram coradas em azul de toluidina em tampão fosfato $0,1 \mathrm{M}$ pH 6,8 e pela reação do ácido periódico-Schiff(PAS). Para a localização da atividade da fosfatase ácida, secções adjacentes foram incubadas em meio de Gomori (Bancroft, 1996), completo ou sem a adição do substrato da enzima ( $\beta$-glicerofosfato de sódio), por 90 min a $37^{\circ} \mathrm{C}$. Amostras de baço de rato, processadas com a mesma resina, foram utilizadas como controle positivo.

Microscopia eletrônica de varredura. Segmentos de $5 \times 5 \mathrm{~mm}$ foram pós-fixados em solução de tetróxido de ósmio $1 \%$ em tampão cacodilato de sódio $0,1 \mathrm{M} \mathrm{pH} \mathrm{7,2} \mathrm{e} \mathrm{desidratados} \mathrm{em} \mathrm{soluções} \mathrm{de} \mathrm{concen-}$ trações crescentes de acetona. Após a secagem ao ponto crítico, os espécimes foram recobertos com ouro e examinados ao microscópio LEO $435 \mathrm{VP}$.

Microscopia eletrônica de transmissão. Amostras de $1 \times 2 \mathrm{~mm}$ foram pós-fixadas em solução de tetróxido de ósmio $1 \%$ em tampão cacodilato de sódio $0,1 \mathrm{M} \mathrm{pH} 7,2$, desidratadas em soluções de concentrações crescentes de acetona e embebidas em resina Spurr. Secções prateadas foram coletadas em telas de cobre e contrastadas em acetato de uranila e citrato de chumbo. Para imunocitoquímica, amostras de $1 \times 2 \mathrm{~mm}$ foram desidratadas em soluções de concentrações crescentes de etanol e embebidas em resina LR White.

Imunomarcação. Secções douradas foram coletadas em telas de níquel e incubadas sucessivamente em leite desnatado $1 \%$, anti-IgG bovino produzido em coelhos (Sigma Chemical Co.) e proteína A conjugada a ouro (Sigma Chemical Co.), com partículas de $20 \mathrm{~nm}$. A contrastação foi feita em acetato de uranila e citrato de chumbo. As amostras foram observadas ao microscópio Zeiss EM 900.

Nivel sérico de IgG. Amostras de sangue da veia jugular foram coletadas dos bezerros imediatamente antes do sacrifício. A concentração sérica de $\operatorname{IgG}$ foi determinada por imunodifusão radial, segundo método modificado de Mancini et al. (1965).

R. Bras. Zootec., v.31, n.6, p.2314-2324, 2002 


\section{Resultados e Discussão}

As concentrações médias de IgG sérica foram $0,762 \pm 1,13 \mathrm{mg} / \mathrm{mL}$ para os bezerros que não mamaram colostro, $13,886 \pm 5,52 \mathrm{mg} / \mathrm{mL}$ para os bezerros que mamaram uma refeição ao nascimento e $26,896 \pm 12,45 \mathrm{mg} / \mathrm{mL}$ para os animais aos três dias de idade, após duas refeições de colostro.

Morfologia do intestino delgado de bezerros recém-nascidos. No duodeno dos bezerros que não receberam colostro, observaram-se vilosidades revestidas por epitélio simples prismático, com as células da região superior das vilosidades apresentando núcleos que ocupam a posição média ou apical (Figura 1). Essas células podiam apresentar vacúolos, principalmente sub-nucleares, não corados e com reação negativa para PAS. As células epiteliais da região inferior das vilosidades eram altas e estreitas, com núcleos localizados na região apical e citoplasmas intensamente corados. As células caliciformes estavam presentes principalmente no terço inferior das vilosidades. Nos recém-nascidos que receberam colostro, as células epiteliais prismáticas também apresentavam núcleos na posição média ou apical, sendo geralmente vacuoladas (Figura 2). Observouse a presença de vacúolos preenchidos por material absorvido no citoplasma basal que, corados por azul de toluidina, apresentavam coloração azul claro.

Nos bezerros que não receberam colostro, nas células epiteliais da porção superior das vilosidades do jejuno proximal foram verificados núcleos na região média ou apical e vacúolos próximos aos núcleos, mas principalmente no citoplasma basal (Figura 4). As células da base das vilosidades apresentaram núcleos apicais e citoplasmas intensamente corados. As células caliciformes estavam presentes principalmente na metade basal das vilosidades. Nos animais que receberam colostro, os enterócitos apresentaram núcleos apicais e vacúolos basais preenchidos por material absorvido (Figura 5). Esse material também estava presente no tecido subepitelial e nos ductos lactíferos. Até mesmo as células basais da vilosidade apresentaram vacúolos dilatados.

A vacuolação aumentou no jejuno médio dos bezerros que não receberam colostro, ocupando o citoplasma apical e basal, enquanto os núcleos estavam no citoplasma apical (Figura 7). As células da base das vilosidades eram mais baixas, com coloração intensa e vacuoladas, mas em menor extensão. As células caliciformes estavam presentes principal- mente na metade inferior das vilosidades. Já nos que receberam colostro, observaram-se grandes vacúolos preenchidos por material absorvido, ocupando toda a célula epitelial e deslocando o núcleo, que não ocupou uma posição fixa (Figura 8). As células da base das vilosidades também apresentaram vacúolos, mas de menor tamanho.

Por microscopia eletrônica de varredura, verificou-se que as vilosidades intestinais do duodeno eram digitiformes, largas e curtas (Figuras 10 e 11), enquanto que as vilosidades do jejuno eram digitiformes, mas delgadas, com tamanho bastante variável (Figura 14).

A célula epitelial da região superior das vilosidades do duodeno de recém-nascidos sem receber colostro apresentou microvilosidades altas e com filamentos basais bem definidos na trama terminal (Figura 16). As numerosas mitocôndrias concentraram-se abaixo da trama terminal e no citoplasma basal. Foram observados ribossomos livres no citoplasma e pequenas cisternas de retículo endoplasmático rugoso dispersas entre as mitocôndrias no citoplasma apical. O complexo de Golgi ocupou posição supra-nuclear. Eram raras as invaginações da membrana intermicrovilosidades, mas uma extensa rede de túbulos endocíticos no citoplasma apical estava estabelecida, sem que houvesse sinal de absorção, confirmada pela ausência de marcação com proteína A-ouro nessas amostras. Já nos bezerros que receberam colostro, as invaginações da membrana entre as microvilosidades foram mais evidentes, sendo observados extensa rede de túbulos, geralmente com aparência vazia, e vacúolos preenchidos por material elétron-denso, com marcação positiva para IgG (Figura 17). Os túbulos eram estreitos ou dilatados e os vacúolos foram observados próximos à membrana lateral. Numa mesma célula foram encontrados vacúolos com aparência vazia ou preenchidos por material de estrutura floculada ou densa. Esses últimos apresentaram marcação positiva para IgG.

Nos enterócitos do jejuno dos bezerros que não receberam colostro, invaginações estavam presentes na base das microvilosidades e uma extensa rede de túbulos ocupava todo o citoplasma apical (Figura 19). Após a ingestão de colostro, os túbulos foram preenchidos por material absorvido (Figura 20). Observou-se a fusão de túbulos com vacúolos, aparentemente descarregando seu conteúdo nessas estruturas já formadas. Houve variações no preenchimento dos vacúolos, que apresentaram material mais disperso ou mais denso. Em algumas amostras, foi

R. Bras. Zootec., v.31, n.6, p.2314-2324, 2002 

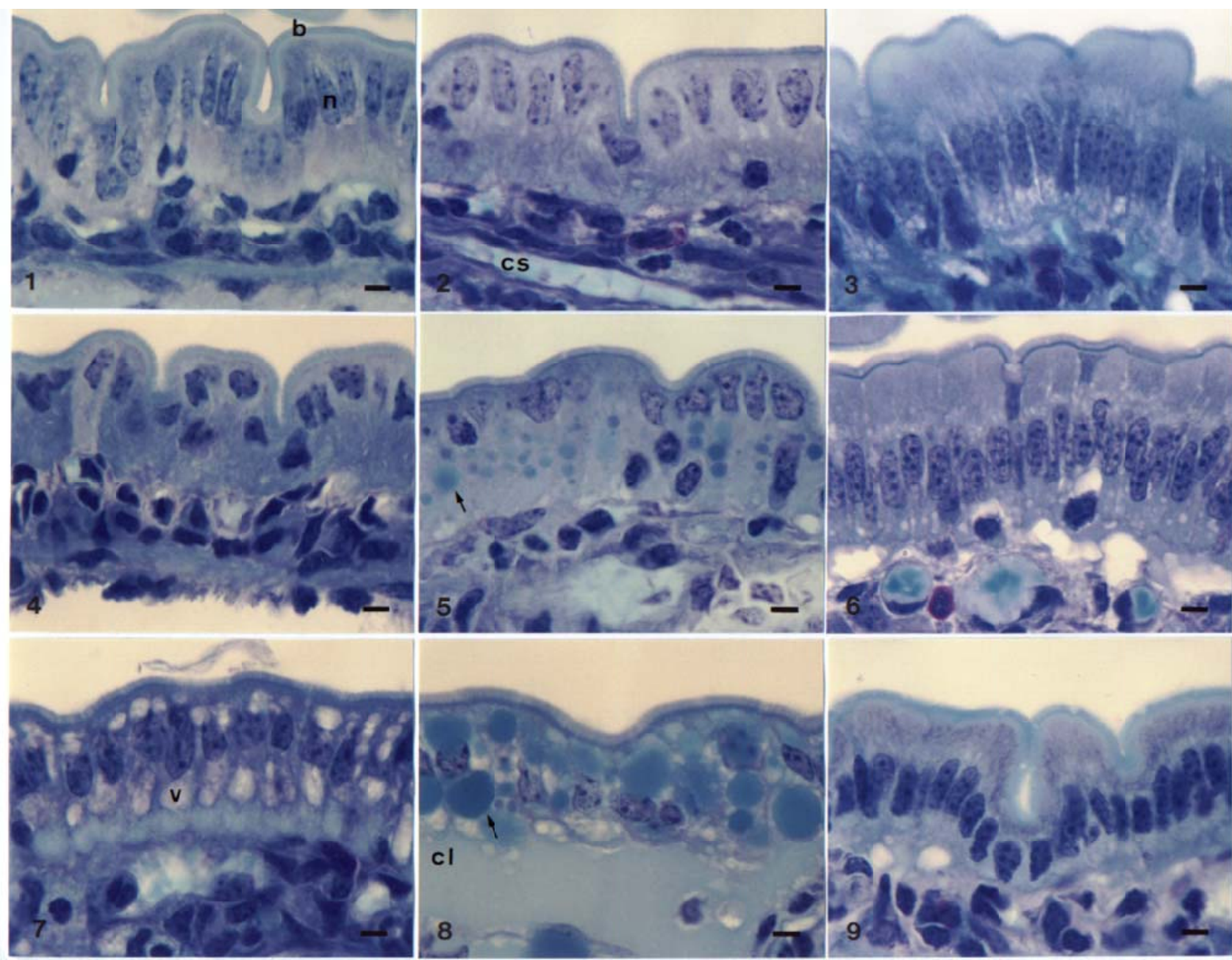

Figura 1 - Epitélio do duodeno de bezerro recém-nascido sem a ingestão de colostro.

Figure 1 - Duodenal epithelium of an unsuckled neonatal calf.

Figura 2 - Epitélio do duodeno de bezerro recém-nascido após a ingestão de colostro.

Figure 2 - Duodenal epithelium of a colostrum fed calf.

Figura 3 - Epitélio do duodeno de bezerro aos três dias de idade.

Figure 3 - Duodenal epithelium of a three-day-old calf.

Figura 4 - Epitélio do jejuno proximal de bezerro recém-nascido sem a ingestão de colostro.

Figure 4 - Proximal jejunal epithelium of an unsuckled neonatal calf.

Figura 5 - Epitélio do jejuno proximal de bezerro recém-nascido após a ingestão de colostro.

Figure 5 - Proximal jejunal epithelium of a colostrum fed calf.

Figura 6 - Epitélio do jejuno proximal de bezerro aos três dias de idade.

Figure 6 - Proximal jejunal epithelium of a three-day-old calf.

Figura 7 - Epitélio do jejuno médio de bezerro recém-nascido sem a ingestão de colostro.

Figure 7 - Medium jejunal epithelium of an unsuckled neonatal calf.

Figura 8 - Epitélio do jejuno médio de bezerro recém-nascido após a ingestão de colostro.

Figure 8 - Medium jejunal epithelium of a colostrum fed calf.

Figura 9 - Epitélio do jejuno médio de bezerro aos três dias de idade.

Figure 9 - Medium jejunal epithelium of a three-day-old calf.

Legenda: n: núcleo; v: vacúolo; cl: capilar linfático; b: bordadura em escova; cs: capilar sanguíneo; seta: material absorvido. Barra $=5 \mathrm{~mm}$.

Legend: $\quad n$ : nucleus; v: vacuole; cl: lacteal; b: brush border; cs: capillar vessel; arrow: absorbed material. Bar $=5 \mathrm{~mm}$.

R. Bras. Zootec., v.31, n.6, p.2314-2324, 2002 


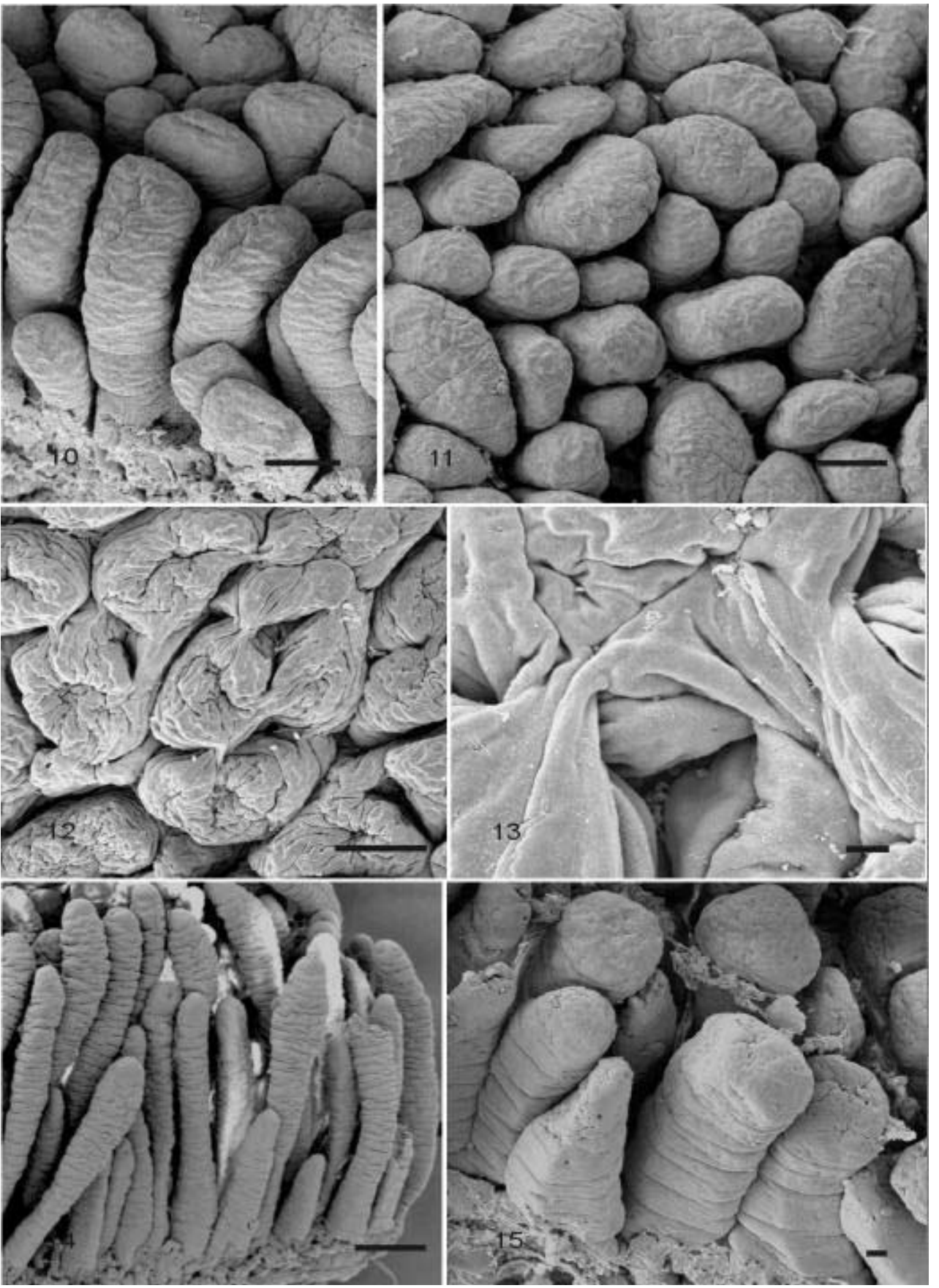

Figura 10 -Vilosidades do duodeno de bezerros recém-nascidos. Barra $=100 \mathrm{~mm}$. Figure 10 - Duodenal villi of a neonatal calf. Bar $=100 \mathrm{~mm}$.

Figura 11 -Vilosidades do duodeno de bezerros recém-nascidos. Barra $=100 \mathrm{~mm}$. Figure 11 - Duodenal villi of a neonatal calf. Bar= $100 \mathrm{~mm}$.

Figura 12 -Vilosidades do duodeno de bezerros aos três dias de idade. Barra $=100 \mathrm{~mm}$. Figure 12 - Duodenal villi of a three-day-old calf. Bar= $100 \mathrm{~mm}$.

Figura 13 -Prolongamentos entre vilosidades duodenais. Barra $=10 \mathrm{~mm}$.

Figure 13 - Bridge-like connections between villi. Ba $r=10 \mathrm{~mm}$

Figura 14 -Vilosidades do jejuno de bezerros recém-nascidos. Barra $=200 \mathrm{~mm}$.

Figure 14 - Jejunal villi of a neonatal calf. Bar $=200 \mathrm{~mm}$.

Figura 15 -Vilosidades do jejuno de bezerros aos três dias de idade. Barra $=20 \mathrm{~mm}$.

Figure 15 - Jejunal villi of a three-day-old calf. Bar $=20 \mathrm{~mm}$.

Legenda: seta: zona de oclusão.

Legend: arrow: extrusion zone. 
possível observar vacúolos menores se fundindo aos maiores pré-formados, com o material elétron-denso mantendo-se próximo à membrana do vacúolo (Figura 22). Nessas células, as microvilosidades eram curtas e esparsas, como se a membrana houvesse se distendido. Vacúolos de diferentes tamanhos foram encontrados próximos às membranas lateral e basal. Utilizando a técnica de imunomarcação com proteína A-ouro foi possível demonstrar que no conteúdo desses vacúolos havia IgG (Figura 23). Numerosas partículas de ouro foram associadas ao material flocular dos diferentes vacúolos, observadas nos tecidos somente após a ingestão de colostro. As partículas estavam associadas ao epitélio, entre as microvilosidades ou dentro dos túbulos do sistema endocítico apical. A marcação foi difusa nos diferentes vacúolos, sendo insignificante nas secções controle.

Morfologia do intestino delgado de bezerros aos três dias de idade. As vilosidades do duodeno apresentavam-se recobertas por tecido epitelial prismático com núcleo ocupando a região média ou basal e vacúolos supra e sub-nucleares, sem coloração (Figura 3). Na base das vilosidades, as células eram mais baixas, com núcleos ovóides e basais. As células caliciformes apresentaram distribuição uniforme ao longo das vilosidades do duodeno. Já nas células epiteliais do jejuno proximal, os núcleos ocuparam posição basal no citoplasma, com a presença de vacúolos que variaram de pequenos, ocupando toda a célula, a grandes e basais (Figura 6). Na base das vilosidades, as células eram mais baixas, com núcleo basal e citoplasma mais intensamente colorido. As células epiteliais do jejuno médio eram semelhantes às já descritas do jejuno proximal (Figura 9).

Aos três dias de idade, as vilosidades do duodeno apresentaram-se achatadas ou nodulares, mais curtas que nos recém-nascidos e com prolongamentos, como pontes, que uniam as vilosidades (Figuras $12 \mathrm{e} 13$ ). As zonas de exclusão estavam bem evidentes nessa idade, no ápice das vilosidades. Já no jejuno, as vilosidades eram menores e mais largas que nos recém-nascidos, com forma digitiforme e tamanho regular (Figura 15).

Nos enterócitos do duodeno e jejuno dos bezerros aos três dias de idade, as microvilosidades eram menores, o sistema endocítico apical reduziu-se; túbulos formados pela invaginação da membrana plasmática e organelas elétron-densas, que correspondem aos lisossomos, estavam próximas à membrana apical (Figuras 18 e 21). Nesses animais, as invaginações e a presença de túbulos diminuíram. No citoplasma apical observou-se a presença de numerosas mitocôndrias, cisternas de retículo endoplasmático rugoso e vacúolos multivesiculares. Não houve marcação com proteína A-ouro nas amostras dos bezerros aos três dias de idade.

Reação da enzima fosfatase ácida. Nos tecidos analisados, foram observados dois padrões de resposta para fosfatase ácida: reação em vacúolos, que consistiu em reação difusa ligada às membranas dos vacúolos e reação em lisossomos, que consistiu na presença de depósitos concentrados em pequenas vesículas no citoplasma apical. Não houve reação enzimática nas amostras quando incubadas com a solução controle, e em tecido de rato, utilizado como controle do procedimento, foi verificada reação positiva na presença do substrato da enzima. Nos recémnascidos que receberam ou não colostro, as amostras de todas as regiões intestinais apresentaram células epiteliais vacuoladas, em maior ou menor extensão. No entanto, apenas um animal que não recebeu colostro apresentou atividade da enzima nos vacúolos do duodeno e jejuno (Figura 24). Já a reação em lisossomos foi verificada somente nas amostras dos bezerros aos três dias de idade, do duodeno ao jejuno médio (Figura 25). Apesar da presença de vacúolos nos enterócitos desses animais, não se observou reação da enzima fosfatase ácida nessas estruturas. De maneira geral, todas as amostras do intestino delgado proximal apresentaram reação de fosfatase ácida na bordadura em escova.

Os níveis de IgG observados estão de acordo com os já descritos por outros autores em bezerros recémnascidos pré-colostrais (McCoy et al., 1970; Bush et al., 1971) e após a ingestão de colostro (McCoy et al., 1970; Machado Neto \& Packer, 1986).

Apesar da importância do fornecimento de colostro e do grande número de trabalhos produzidos para o estabelecimento de um bom manejo de recémnascidos, pouco se estudou do processo de absorção de anticorpos nas células do epitélio intestinal de bezerros (Staley et al., 1972; Jochims et al., 1994; Kaup et al., 1996).

De acordo com Mellman (1996), endocitose ocorre em maior ou menor intensidade em todas as células eucariontes. O fluido extracelular, internalizado por esse mecanismo, é processado em um complexo sistema intracelular de endossomos e túbulos, com progressiva diminuição do $\mathrm{pH}$ interno, sendo os lisossomos o compartimento final, que contêm as

R. Bras. Zootec., v.31, n.6, p.2314-2324, 2002 

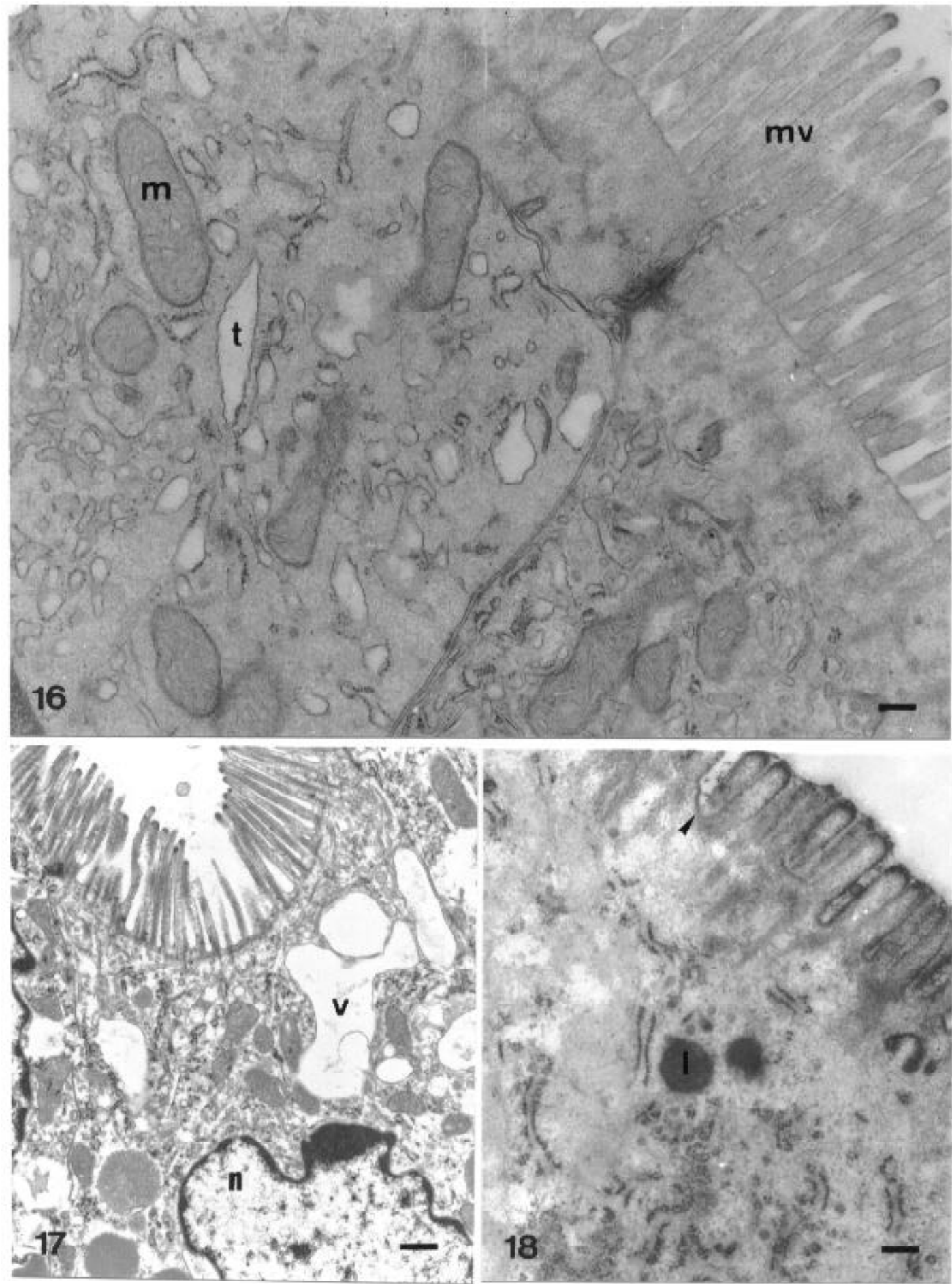

Figura 16 - Citoplasma apical de enterócito duodenal de bezerro recém-nascido. Barra $=0,25 \mathrm{~mm}$.

Figure 16 - Apical end of duodenal enterocyte of an unsuckled neonatal calf. Bar $=0.25 \mathrm{~mm}$.

Figura 17 - Citoplasma apical de enterócito duodenal de bezerro após a ingestão de colostro. Barra $=0,6 \mathrm{~mm}$.

Figure 17 - Apical end of duodenal enterocyte of a colostrum fed calf. Bar $=0.6 \mathrm{~mm}$.

Figura 18 - Citoplasma apical de enterócito duodenal de bezerro aos três dias de idade. Barra $=0,25 \mathrm{~mm}$.

Figure 18 - Apical end of duodenal enterocyte of a three-day-old calf. Bar $=0.25 \mathrm{~mm}$.

Legenda: mv: microvilosidades; v: vacúolo; m: mitocôndria; I: lisossomo; t: túbulo; ponta de seta: invaginação da membrana apical. Legend: $\quad$ mv: microvilli; $v$ : vacuole; m: mitochondria; $I$ : lysosome; $t$ : tubule; arrowhead: membrane invagination. 


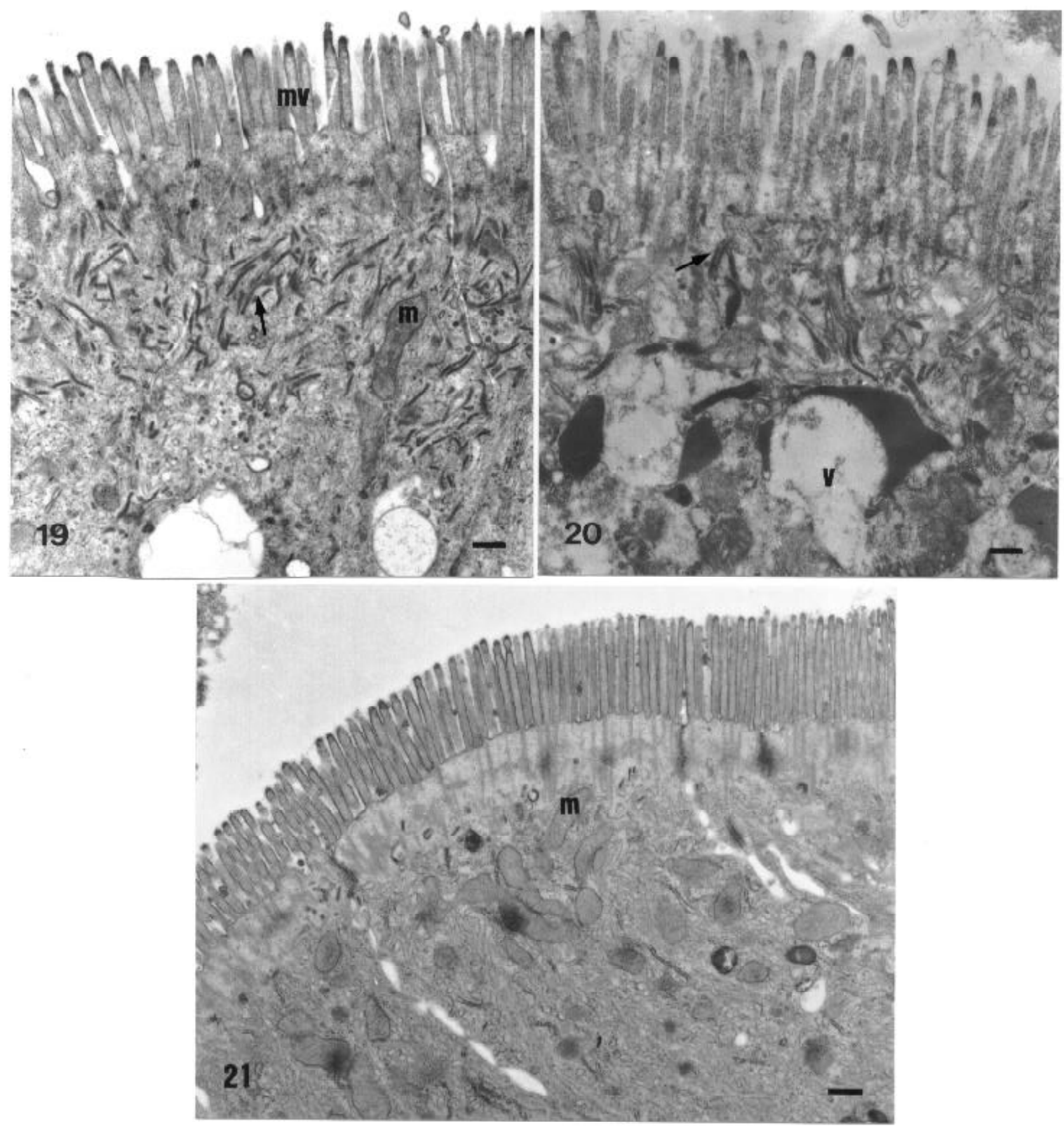

Figura 19 - Citoplasma apical de enterócito do jejuno de bezerro sem a ingestão de colostro. Barra $=0,36 \mathrm{~mm}$. Figure 19 - Apical end of jejunal enterocyte of an unsuckled neonatal calf. Bar $=0.36 \mathrm{~mm}$.

Figura 20 - Citoplasma apical de enterócito do jejuno de bezerro após a ingestão de colostro. Barra $=0,36 \mathrm{~mm}$. Figure 20 - Apical end of jejunal enterocyte of a colostrum fed calf. Bar $=0.36 \mathrm{~mm}$.

Figura 21 - Citoplasma apical de enterócito do jejuno de bezerro aos três dias de idade. Barra $=0,5 \mathrm{~mm}$.

Figure 21 - Apical end of jejunal enterocyte of a three-day-old calf. Bar $=0.5 \mathrm{~mm}$.

Legenda: mv: microvilosidades; seta: túbulos; v: vacúolo; m: mitocôndrias; I: lisossomo.

Legend: $\quad$ mv: microvilli; arrow: tubules; v: vacuole; m: mitochondria; l: lysosome.

R. Bras. Zootec., v.31, n.6, p.2314-2324, 2002 

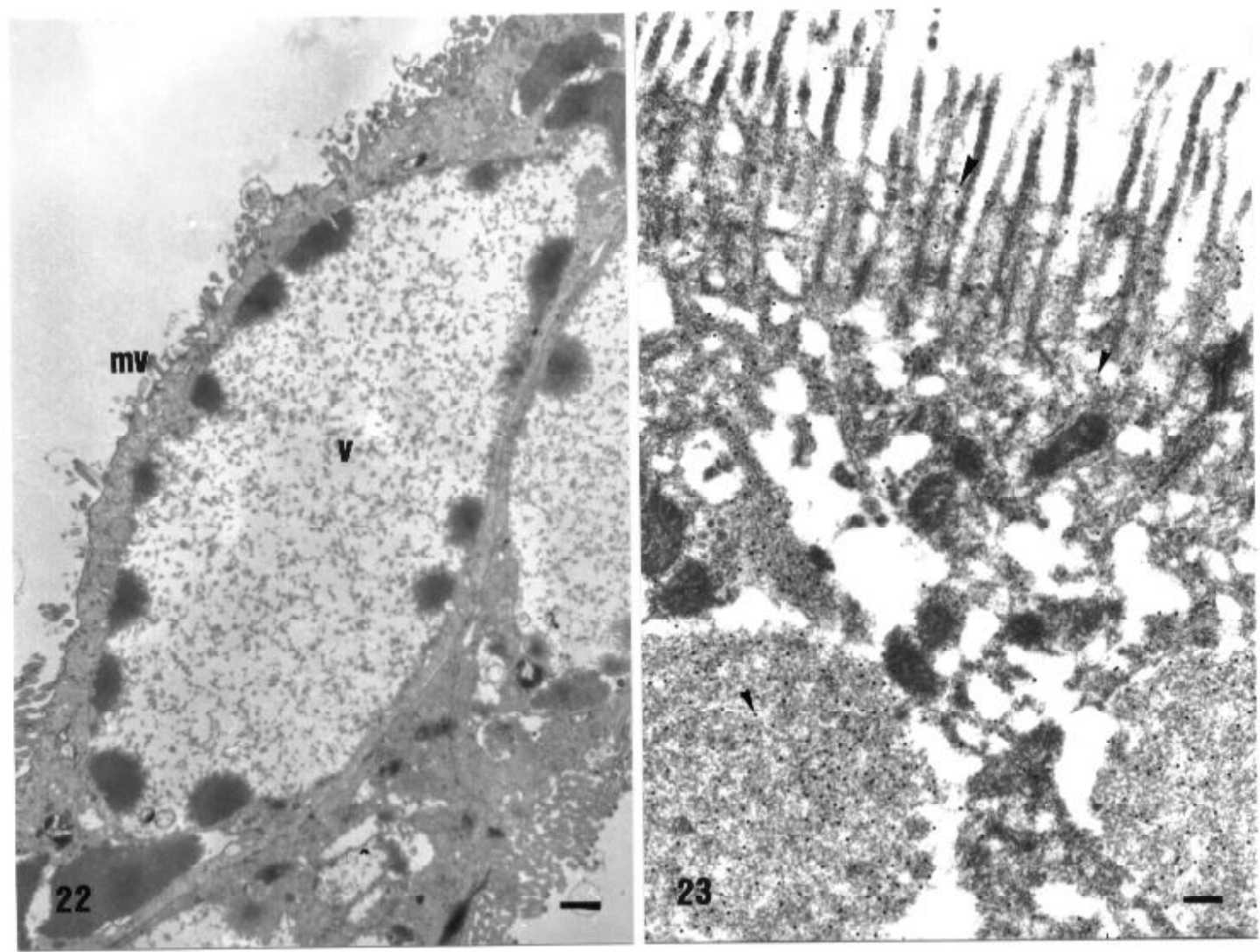

Figura 22 - Célula vacuolada do jejuno de bezerro após a ingestão de colostro. Barra = 1,25 mm.

Figure 22 - Jejunal vacuolated cell of a colostrum fed calf. Bar $=1.25 \mathrm{~mm}$.

Figura 23 - Localização de IgG no citoplasma apical de enterócito de jejuno de bezerro. Barra = 0,3 $\mathrm{mm}$.

Figure 23 - IgG localization in the apical end of jejunal enterocyte of a calf. Bar $=0.3 \mathrm{~mm}$.

Legenda - mv: microvilosidades; v: vacúolo; ponta de seta: partículas de ouro.

Legend - mv: microvilli; v: vacuole; arrowhead: gold particle.

enzimas hidrolíticas. Quando uma proteína está no fluído da vesícula endocítica pode seguir para a via catabólica, o destino da maioria, ou ser protegida pela ligação a um receptor no endossomo (Telleman \& Junghans, 2000). Essa última via é que permite a transferência de IgG em ratos recém-nascidos. As imunoglobulinas se ligam aos receptores na membrana apical, atravessam a célula, sendo liberadas, sem sofrerem degradação, na membrana basolateral dos enterócitos do intestino delgado proximal. As características histológicas do processo endocítico, observado no intestino delgado de bezerros recém-nascidos, não sustentam a existência de mecanismo semelhante. São 24 a 48 horas de transporte massivo de conteúdo do lume intestinal para a lâmina própria da mucosa intestinal, com pouca seletividade (Balfour \& Comline, 1959; Staley et al., 1972). Aparentemente, não haveria tempo para o desenvolvimento pós-natal do sistema de transporte. Já ao nascimento, as células apresentam vacúolos claros, visíveis ao microscópio óptico, e um sistema apical de túbulos e vesículas estabelecido para desempenhar sua função.

Túbulos, formados por invaginação da membrana intermicrovilosidades, transferem a ingesta para o citoplasma apical. Esses túbulos fundem-se a vacúolos, concentrando o material absorvido, podendo formar grandes vacúolos que ocupam toda célula, deslocando núcleos e organelas para a região periférica do citoplasma. Essa característica é mais evidente no jejuno, no qual se observam células com 


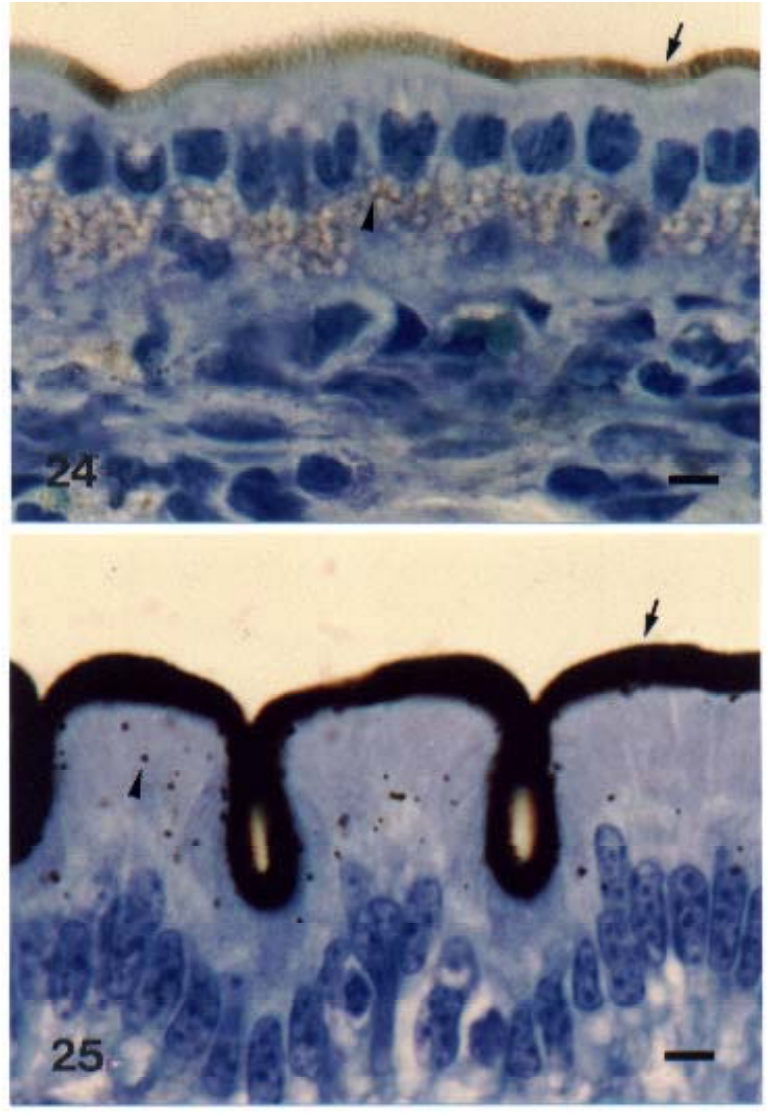

Figura 24 - Reação de fosfatase ácida no epitélio do jejuno de bezerro recém-nascido sem a ingestão de colostro.

Figure 24 - Acid phosphatase reaction in jejunal epithelium of an unsuckled neonatal calf

Figura 25 - Reação de fosfatase ácida no epitélio do jejuno de bezerro aos três dias de idade.

Figure 25 - Acid phosphatase reaction in jejunal epithelium of a three-day-old calt.

Legenda: ponta de seta: reação de fosfatase ácida em lisossomos; seta: material absorvido. Barra $=5 \mathrm{~mm}$

Legend: $\quad$ arrowhead: lysosomes acid phosphatase reaction; arrow: absorbed material. Bar $=5 \mathrm{~mm}$.

vacúolos em diferentes estágios de preenchimento: com material flocular disperso, com material denso e uniforme ou, ainda, material aderido às membranas, como se um vacúolo menor acabasse de descarregar seu conteúdo. Vacúolos foram observados próximos às membranas lateral e basal dos enterócitos, mas o processo de exocitose não foi observado neste trabalho. Acredita-se que esse é um processo extrema- mente rápido, de difícil observação (Baintner, 1986; Jochims et al., 1994). Material absorvido também é encontrado no espaço extracelular e no interior de capilares linfáticos, que no intestino são fenestrados. Esse processo pinocítico não seletivo, de formação de pequenas vesículas carregando fluido e macromoléculas, parece predominar no transporte de imunidade materna em bezerros. No entanto, há dúvidas sobre a existência de um mecanismo específico de menor importância, uma vez que já foram observadas IgG em cavidades recobertas por clatrina no jejuno de bezerros recém-nascidos (Jochims et al., 1994).

A reação da enzima fosfatase ácida em vacúolos basais de um dos bezerros recém-nascidos, indicando a presença de enzimas hidrolíticas nessas estruturas, ainda não havia sido verificada em bezerros dessa idade. Jochims et al. (1994) verificaram a presença de estruturas semelhantes a heterolisossomos em células do jejuno de bezerros, mas somente às 24 horas de vida. O significado é incerto. Em leitões, Brown \& Moon (1979) sugeriram que havia um tempo de espera de 16 a 24 horas após o nascimento para a ativação da digestão intracelular, mas Baintner (1994) observou acidez nos vacúolos absortivos de leitões recém-nascidos. Considerando-se a quantidade de proteína transportada e o período reduzido do processo de absorção, parece improvável que ocorra atividade proteolítica significativa durante a transcitose das imunoglobulinas. Em cultura de células BHK, observou-se que a enzima fosfatase ácida é transportada como uma proteína transmembrana para os lisossomos, incluindo a passagem pela membrana plasmática. Ela é transportada do trans-Golgi para a membrana plasmática de onde é internalizada, o que explicaria a presença de atividade de fosfatase ácida na bordadura em escova (Braun et al., 1989).

Grandes mudanças ocorrem num período muito curto, as quais são evidentes ao se comparar a forma e o tamanho das vilosidades ao microscópio eletrônico de varredura. O duodeno, em apenas três dias, passa a apresentar vilosidades baixas, com a superfície aparentemente plana, como uma zona de transição do estômago para a região de importância para a absorção, o jejuno. A presença de prolongamentos entre vilosidades já havia sido observada por Landsverk (1979), mas em bezerros com aproximadamente três semanas de idade. O jejuno do recémnascido apresentou vilosidades de tamanho bastante variável, o que poderia representar diferentes estratos para aumentar a superfície exposta para a absor-

R. Bras. Zootec., v.31, n.6, p.2314-2324, 2002 
ção de colostro. Já no jejuno dos bezerros aos três dias, as vilosidades mostraram tamanho menor e mais uniforme, o que também foi observado em bezerros de dois dias por Mebus et al. (1975) e de três semanas de idade por Landsverk (1979). A posição basal dos núcleos, observada por microscopia óptica aos três dias de idade, também foi verificada por Landsverk (1979), sendo relacionada à presença de um epitélio mais maduro em bezerros de três semanas de idade.

A morfologia do intestino delgado de bezerros aos três dias de idade pode representar diferente estágio de maturação. Uma nova população de células estava presente, com núcleos deslocados para a posição basal e com sistema endocítico reduzido a pequenos túbulos apicais. Os lisossomos foram evidentes e a vacuolação citoplasmática diminuiu. Assim, o fechamento intestinal parece estar relacionado à presença de uma segunda população de células epiteliais, extremamente diferente da presente ao nascimento. Se a ingestão de alimento, a presença de fatores do colostro, como hormônios e peptídeos bioativos, ou o início da atividade digestiva no animal afetam essa substituição, ainda está para ser conclusivamente estabelecido.

\section{Conclusões}

O processo de absorção de anticorpos do colostro está relacionado à primeira geração de células epiteliais do duodeno e jejuno.

\section{Literatura Citada}

BAINTNER, K. Demonstration of acidity intestinal vacuoles of the suckling rat and pig. Journal of Histochemistry and Cytochemistry, v.42, n.2, p.231-238, 1994.

BAINTNER, K. Intestinal absorption of macromolecules and immune transmission from mother to young. Boca Raton: CRC Press, 1986. 240p.

BALFOUR, W.E.; COMLINE, R.S. The specificity of the intestinal absorption of large molecules by the new-born calf. Journal of Physiology, v.148, n.3, p.77-78, 1959.

BANCROFT, J.D.; STEVENS, A. Enzyme histochemistry: theory and practice of histological techniques. New York: Churchill Livingstone, 1996. 766p.

BRAMBELL, F.W.R. The passive immunity of the young mammal. Biological Reviews, v.33, n.4, p.488-531, 1958.

BRAUN, M.; WAHEED, A.; FIGURA, K. Lysosomal acid phosphatase is transported to lysosomes via the cell surface. EMBO Journal, v.8, n.12, p.3633-3640, 1989.

BROWN, H.H., MOON, H.W. Localization and activities of lysosomal enzymes in jejunal and ileal epithelial cells of the young pig. American Journal of Veterinary Research, v.40, n.11, p.1573-1577, 1979.
BUSH, L.J.; AGUILERA, M.A.; ADAMS, G.D. Absorption of colostral immunoglobulins by newborn dairy calves. Journal of Dairy Science, v.54, n.10, p.1547-1549, 1971.

HASEGAWA, H.; NAKAMURA, A.; WATANABE, K. et al. Intestinal uptake of IgG in suckling rats. Gastroenterology, v.92, n.1, p.186-191, 1987.

JAMES, R.E.; POLAN, C.E.; McGILLIARD, M.L. Distributional uptake of $\mathrm{g}$-globulin in small intestine of neonatal calves. Journal of Dairy Science, v.62, n.9, p.1415-1419, 1979.

JOCHIMS, K.; KAUP, F.J.; DORMMER, W. An immunoelectron microscopic investigation of colostral IgG absorption across the intestine of newborn calves. Research in Veterinary Science, v.57, n.1, p.75-80, 1994.

KAUP, F.J.; DORMMER, W.; JOCHIMS, K. et al. Ultrastructure of pre- and postcolostral enterocytes of the newborn calf. Anatomia Histologia Embryologia, v.25, n.4, p.249-255, 1996.

KRAEHENBUHL, J.P.; CAMPICHE, M.A. Early stages of intestinal absoption of specific antibodies in the newborn. Journal of Cell Biology, v.42, n.2, p.345-365, 1969.

LANDSVERK, T. The gastrointestinal mucosa in young milkfed calves. Acta Veterinaria Scandinavica, v.20, n.4, p.572-582, 1979.

MACHADO NETO, R.; PACKER, I.U. Flutuação de imunoglobulina sérica em bezerros da raça holandesa submetidos a diferentes regimes de aleitamento. Revista da Sociedade Brasileira de Zootecnia, v.15, n.5, p.439-447, 1986.

MANCINI, G.; CARBONARA, A.O.; HERMANS, J.F. Immunochemical quantitation of antigens by single radial immunodiffusion. Immunochemistry, v.2, p.253-254, 1965.

McCOY, G.C.; RENEAU, J.K.; HUNTER, A.G. et al. Effects of diet and time on blood serum proteins in the newborn calf. Journal of Dairy Science, v.53, n.3, p.358-362, 1970.

MEBUS, C.A.; NEWMAN, L.E.; STAIR, E.L. Scanning electron, light, and transmission electron microscopy of intestine of gnotobiotic calf. American Journal of Veterinary Research, v.36, n.7, p.985-993, 1975.

MELlman, I. Endocytosis and molecular sorting. Annual Review of Cell and Developmental Biology, v.12, p.575625, 1996.

RODEWALD, R. Distribution of immunoglobulin G receptors in the small intestine of the young rat. Journal of Cell Biology, v.85, n.1, p.8-32, 1980.

RODEWALD, R. Intestinal transport of antibodies in the newborn rat. Journal of Cell Biology, v.58, n.1, p.189-211, 1973.

RODEWALD, R. pH-dependent binding of immunglobulins to intestinal cells of the neonatal rat. Journal of Cell Biology, v.71, n.2, p.666-670, 1976.

STALEY, T.E.; CORLEY, L.D.; BUSH, L.J. et al. The ultrastructure of neonatal calf intestine and absorption of heterologous proteins. Anatomical Record, v.172, n.3, p.559$580,1972$.

TELLEMAN, P.; JUNGHANS, R.P. The role of the Brambell receptor $(\mathrm{FcRB})$ in liver: protection of endocytosed immunoglobulin $\mathrm{G}$ (IgG) from catabolism in hepatocytes rather than transport of IgG to bile. Immunology, v.100, n.2, p.245-251, 2000 . 